\title{
TWO EUROPEAN SPECIES OF CHELOSTOMA ESTABLISHED IN NEW YORK STATE (HYMENOPTERA: MEGACHILIDAE)*
}

\author{
By George C. Eick wort \\ Department of Entomology \\ Cornell University \\ Ithaca, New York 14853
}

\section{INTRODUCTION}

Chelostoma is a Holarctic genus of slender, black megachiline bees that is widespread in the Palearctic region and has eight species in western North America. The Nearctic species all occur in California, with the range of two extending northward to Washington, one of which also occurs eastward to Utah and Idaho (Hurd and Michener, 1955). No native Chelostoma occur east of the Rocky Mountains. Chelostoma is replaced east of the Great Plains by the closely related genus Prochelostoma, which contains one species, P. philadelphi (Robertson). However, Chelostoma has recently become established in northeastern United States, where two European species, C. campanularum (Kirby) and C. fuliginosum (Panzer), have been collected in several localities in central New York State (Fig. 1).

\section{TAXONOMY}

Both European species key to Chelostoma in the keys to genera of Megachilini in Michener (1944) and Hurd and Michener (1955). Like the native Nearctic Chelostoma, the two European species possess a longitudinal carina along the inner ventral angle of each hind coxa and have the third segment of the labial palp flattened and connate with the second. These characters are often difficult to see in pinned specimens. This was of little practical consequence because they served in keys to separate Chelostoma from Prochelostoma, and the native ranges of these genera do not overlap. Prochelostoma philadelphi, however, is common in New York where the European Chelostoma are now established. I suggest the

*Manuscript received by the editor May 7, 1981. 


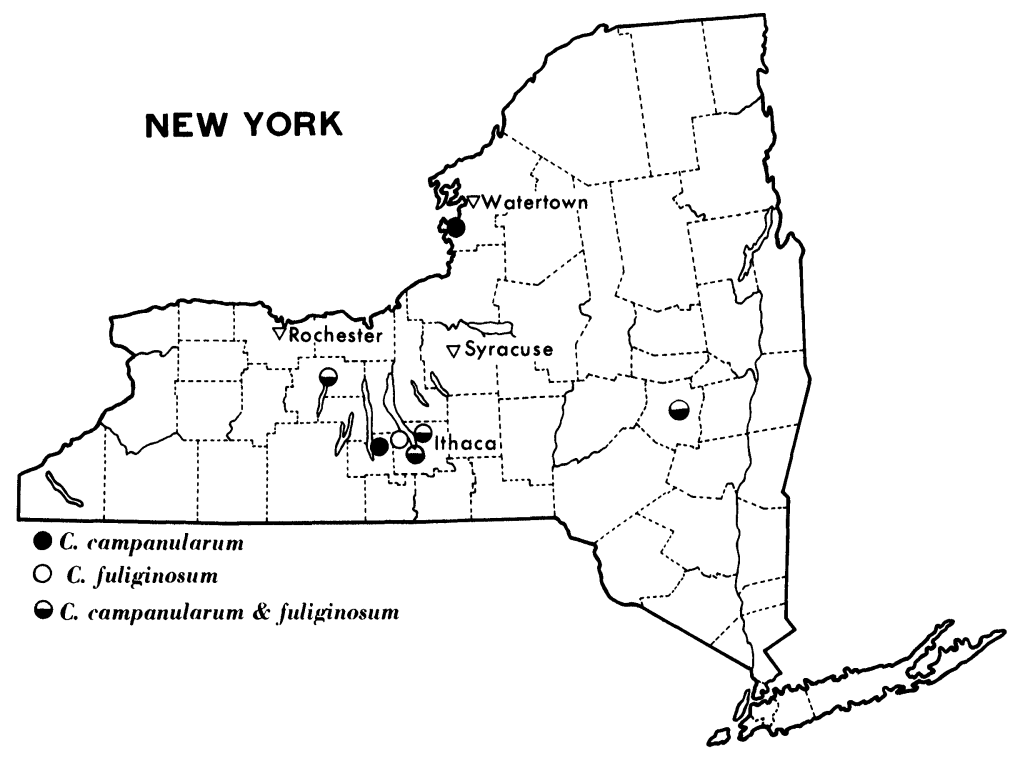

Figure 1. Distribution of Chelostoma in New York State.

following modification of Mitchell's (1962, p. 5) key to genera of eastern United States Megachilidae:

11. Metasomal (=gastral $\left.{ }^{1}\right)$ tergum I with anterior surface broadly concave, distinctly separated from dorsal surface by line or carina ..................................

Metasomal tergum I with anterior surface at most narrowly concave or merely sulcate medially, not separated from dorsal surface by line or carina $\ldots \ldots \ldots \ldots \ldots \ldots \ldots . \ldots \ldots$

12 (11). Anterior concavity of metasomal tergum I lined dorsally by sharply carinate rim; anterior surface of mesepisternum not separated from lateral surface by carina ......... Heriades Anterior concavity of metasomal tergum I not lined by distinct carina; anterior surface of mesepisternum nearly impunctate, separated from lateral surface by carina ..... Ashmeadiella

13 (11). Propodeum with distinct, horizontal, pitted or rugose basal zone; form slender, shortest distance between tegulae equal to or less than length of mesoscutum .................14

1. =abdominal of Mitchell (1962). 
Propodeum sloping to posterior surface, without distinct, horizontal, basal zone; form robust to slender, shortest distance between tegulae greater than length of mesoscutum

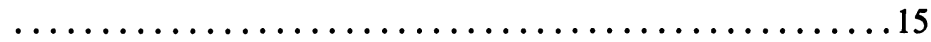

14 (13). Labial palp with 2 free segments; female with clypeus emarginate apically and with mandible over $3 / 4$ as long as eye (Fig. 3); male with apex of metasomal tergum VII quadridentate, lateral teeth short and obtuse (Fig. 4) ............ ..............................Prochelostoma

Labial palp with 1 free segment; female with clypeus uniformly convex and with mandible less than $2 / 3$ as long as eye (Fig. 2); male with apex of metasomal tergum VII bidentate (Fig. 5) or with 3 truncate processes (Fig. 6) ......... Chelostoma 15 (13). Notaulices elongate-linear; black (in all eastern species) .Hoplitis

Notaulices punctiform-oval; usually metallic blue or green, rarely black ....................... Osmia

The males of the two introduced species of Chelostoma can be readily distinguished by the different shapes of their metasomal terga VII (Figs. 5-6). Female C. fuliginosum have apical, white, pubescent bands on metasomal terga I-IV; these bands are absent in $C$. campanularum. The size ranges of the two species do not overlap.

Chelostoma campanularum is synonymized with C. florisomne (Linnaeus) in some European literature (i.e., Schmiedeknecht, 1930; Stoeckhert, 1933, 1954), but florisomne is actually a senior synonym of C. maxillosum (Linnaeus) (Richards, 1935). Chelostoma campanularum is a common species throughout Europe (except the far north), and occurs in Great Britain and north Africa. It is only 4.0 to $6.0 \mathrm{~mm}$ long and in general appearance greatly resembles smaller specimens of Prochelostoma philadelphi and to a lesser extent very small specimens of some species of Hoplitis (Alcidamea).

Chelostoma fuliginosum is frequently cited in the European literature under its junior synonyms $C$. nigricorne (Nylander) and $C$. rapunculi (Lepeletier). A complete synonymy, including three other, less-used, junior synonyms, is given by Tkalcu (1967). This species is common in northern and central Europe, although it is absent from Great Britain. It occurs sporadically in southern Europe and its range extends across the Soviet Union to Siberia. It is 7.0 to $9.0 \mathrm{~mm}$ 

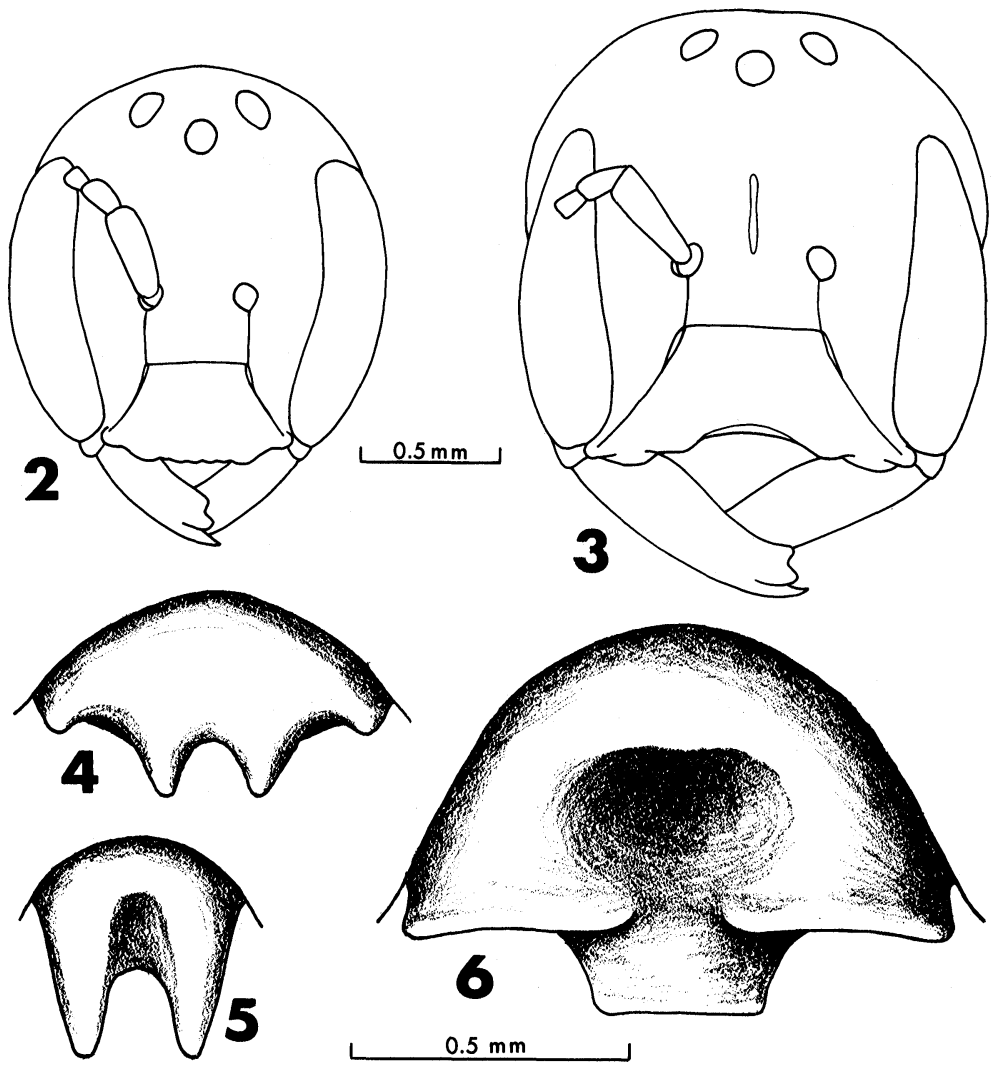

Figures 2-6. Fig. 2. Anterior view of head of Chelostoma campanularum, female. Fig. 3. Anterior view of head of Prochelostoma philadelphi, female. Fig. 4. Caudal view of metasomal tergum VII of $P$. philadelphi, male. Fig. 5. Caudal view of metasomal tergum VII of C. campanularum, male. Fig. 6. Caudal view of metasomal tergum VII of Chelostoma fuliginosum, male. 
long, much larger than C. campanularum, and in general appearance more closely resembles some species of Hoplitis than it does $C$. campanularum and $P$. philadelphi.

Additional characters to distinguish northeastern Hoplitis from the introduced Chelostoma include the clypeal apex of the female, which in Hoplitis is flattened and greatly overhangs the base of the labrum, ${ }^{2}$ while in Chelostoma it is evenly convex and barely exceeds the base of the labrum. The apex of metasomal tergum VII of male Hoplitis is broadly rounded, truncate, or with a single median spine, unlike that of either species of Chelostoma (Figs. 5-6).

Voucher specimens of $C$. campanularum and fuliginosum are deposited in the Cornell University insect collection, lot number 995, and in the American Museum of Natural History, The U. S. National Museum of Natural History, the University of Kansas Snow Museum, and the Museum of Comparative Zoology at Harvard University.

\section{BIOLOGY}

The biology of both species of Chelostoma in Europe has been studied; the most thorough account is by Käpylä (1978) in Finland (in which $C$. fuliginosum is cited as $C$. rapunculi). Nests of $C$. fuliginosum (cited as $C$. nigricorne) in Italy have been briefly described by Bonelli (1967), and in France by Correia (1976), and nests of $C$. campanularum (as C. florisomne) in Italy have been described by Grandi (1961).

Both species are univoltine, mid-to-late-summer bees, with flight periods in Europe from May or June to August or September (Benoist, 1929; Stoeckhert, 1933; Correia, 1976; Käpylä, 1978). New York specimens of $C$. campanularum in the Cornell collection were captured from $1 \mathrm{July}$ to $27 \mathrm{July}$, while specimens of $C$. fuliginosum were captured from 4 June to 26 July.

Chelostoma campanularum and fuliginosum are both strictly oligolectic for pollen on bellflowers, Campanula (Campanulaceae), although other flowers are commonly visited for nectar (Käpylä, 1978) . In contrast, the western Nearctic Chelostoma are all or mostly oligolectic on Hydrophyllaceae, especially Phacelia and Eriodictyon (Hurd and Michener, 1955). Prochelostoma philadel-

2. Except in Hoplitis (H.) anthocopoides, which is a robust, Osmia-shaped species. 
phi also collects pollen from Hydrophyllaceae (Hydrophyllum) as well as mock-orange, Philadelphus (Saxifragaceae) (Robertson, 1929), the plant on which it is most commonly collected in New York. In New York both species of Chelostoma commonly visit creeping bellflower, Campanula rapunculoides, a roadside weed introduced from Europe, which they share with the native oligolectic megachilid bee Chalicodoma campanulae (Robertson) and numerous polylectic bees. The Chelostoma also visit the native harebell, Campanula rotundifolia, as well as other introduced species of Campanula in gardens. Males of both species patrol Campanula and attempt to copulate with foraging females, as Käpylä (1978) observed in Finland. Males of $C$. fuliginosum and both sexes of $C$. campanularum often sleep in flowers of Campanula (Käpylä, 1978).

Both species construct their nests in pre-existing cavities. They prefer holes in old wood, including stumps, posts, and structural timbers (Frey-Gessner, 1909; Benoist, 1929; Stoeckhert, 1933; Käpylä, 1978). Chelostoma fuliginosum will accept trap nests (Bonelli, 1967; Correia, 1976) and C. campanularum will nest in straws (FreyGessner, 1909; Grandi, 1961). Chelostoma campanularum uses 2.0to 2.5-mm-diameter cavities while $C$. fuliginosum uses 4.0- to 5.0$\mathrm{mm}$-diameter cavities. Neither species lines its cell walls with foreign materials, and both construct their cell partitions and final closures with soil mixed with nectar (Käpylä, 1978), although Bonelli (1967) described a nest of $C$. fuliginosum with resin partitions.

\section{Distribution in New York State}

The earliest collections of $C$. campanularum and fuliginosum in New York were made in 1973 and 1962, respectively. The presently known range in New York is illustrated in Figure 1. Both species have been collected in Schoharie, Tompkins, and Ontario Counties, and C. campanularum has also been collected in Schuyler and Jefferson Counties. This is certainly not a complete picture, because there has been no systematic effort to collect these bees. Entomologists throughout the Northeast should watch their local bellflowers for Chelostoma. 


\section{Discussion}

At least eight exotic species of Megachilidae have accidentally become established in North America. Eickwort (1971) discussed five of these species: Megachile rotundata (Fabricius) (=pacifica (Panzer)), Megachile concinna Smith, Megachile apicalis Spinola, Chalicodoma lanata (Fabricius), Anthidium manicatum (Linnaeus), and Hoplitis anthocopoides (Schenck). Roberts (1978) has recently recorded the establishment in New Jersey of Lithurge chrysurus Fonscolombe, a native of the Mediterranean region, and the present paper reports the establishment of two Palearctic species of Chelostoma in New York. In addition, Osmia cornifrons (Radoszkowski) has been purposely introduced for fruit pollination into Utah and Maryland from Asia and appears to be established, at least in Maryland (Batra, 1979 and personal communication).

Although many megachilid bees excavate nests in soil (Eickwort et al., 1981), all of these introduced species construct nests in cavities, bore into wood, or construct free-standing masonry nests. Human transport of substrates containing nests with diapausing bees probably was their mode of immigration. All of the introduced megachilids live in disturbed habitats and visit Old World garden flowers and weeds, either as generalists (Megachile spp., Chalicodoma lanata, Anthidium manicatum) or as specialists (Chelostoma fuliginosum and campanularum on Campanula, Hoplitis anthocopoides on Echium, and Lithurge chrysurus on Centaurea). The two species of Chelostoma compete for the same food resource but use different-diameter cavities for nests.

Surprisingly, four of these eight species are known only from central New York State $\left(H\right.$. anthocopoides ${ }^{3}, A$. manicatum, $C$. fuliginosum, and C. campanularum). Indeed, on a pleasant July day the latter three species plus $M$. rotundata forage simultaneously in one of Cornell University's beautiful gardens. Ithaca, New York, is hardly a major port of entry, so I cannot explain this apidological touch of Europe that we enjoy.

3. After this paper was accepted for publication, Hoplitis anthocopoides was captured in Frederick Co., Virginia. 


\section{SUMMARY}

The Palearctic species Chelostoma campanularum and fuliginosum have recently become established in central New York State. Mitchell's key to eastern U. S. megachilid genera is revised to include Chelostoma. They are distinguished from similar New York Megachilidae (Prochelostoma and Hoplitis) by the shape of metasomal tergum VII of the males and the clypeal apex of the females. Both species are oligolectic on bellflowers, Campanula, and construct nests in pre-existing cavities, primarily in old wood. Nine exotic species of megachilid bees have become established in North America, of which four ${ }^{4}$ are known only from New York State.

\section{ACKNOWLEDGEMENTS}

I thank my associates at Cornell University, especially Dr. Howard Ginsberg, Ms. Barbara Kurtak, and Dr. L. L. Pechuman, for collecting specimens of Chelostoma. Mr. G. van der Zanden of Eindhoven, the Netherlands, confirmed my determinations of the species. Dr. Paul D. Hurd, Jr., of the U. S. National Museum of Natural History critically read the manuscript. Portions of this research were supported by National Science Foundation grant number DEB-78-03151.

\section{Literature Cited}

Batra, S. W. T.

1979. Osmia cornifrons and Pithitis smaragdula, two Asian bees introduced into the United States for crop pollination. Proc. 4th Int. Symp. Pollination, Md. Agric. Exp. Sta. Spec. Misc. Publ. 1: 307-312.

Benoist, R.

1929. Les Heriades de la faune Française. Ann. Entomol. Soc. France 98: 131-141.

BONELLI, B.

1967. Osservazioni biologiche sugli Imenotteri melliferi e predatori della Val di Fiemme. XXVI. Boll. Ist. Entomol. Univ. Bologna 28: 305-317.

Correia, M. de L. M. de A.

1976. Fluctuations de populations naturelles chez les genres Chelostoma et Heriades (Hymenoptera Megachilidae). Apidologie 7: 189-195.

EICKwort, G. C.

1971. Hoplitis anthocopoides, a European mason bee established in New York State (Hymenoptera: Megachilidae). Psyche 77: 190-201.

Eickwort, G. C., R. W. Matthews, and J. Carpenter

1981. Observations on the nesting behavior of Megachile rubi and M. texana with a discussion of the significance of soil nesting in the evolution of

4. See footnote 3 on previous page. 
megachilid bees (Hymenoptera: Megachilidae). J. Kans. Entomol. Soc., in press.

Frey-Gessner, E.

1909. Fauna insectorum helvetiae. Hymenoptera Apidae vol. II. Bauchsammler und Schmarotzerbienen. Mitt. Schweiz. Entomol. Gesel. 11, suppl.: $256 \mathrm{p}$.

Grandi, G.

1961. Studi di un entomologo sugli Imenotteri superiori. Boll. Ist. Entomol. Univ. Bologna 25: 1-659.

Hurd, P. D., JR., AND C. D. Michener

1955. The megachiline bees of California (Hymenoptera: Megachilidae). Bull. Calif. Insect Survey 3: 247 p.

KÄPYLÄ, M.

1978. Bionomics of five wood-nesting solitary species of bees (Hym., Megachilidae), with emphasis on flower relationships. Biol. Res. Rep. Univ. Jyväskylä 5: 3-89.

Michener, C. D.

1944. Comparative external morphology, phylogeny, and a classification of the bees (Hymenoptera). Bull. Amer. Mus. Nat. Hist. 82: 151-326.

Mitchell, T. B.

1962. Bees of the eastern United States. Vol. II. N. Car. Agric. Exp. Sta. Tech. Bull. 152: $557 \mathrm{p}$.

RICHARDS, O. W.

1935. Notes on the nomenclature of the aculeate Hymenoptera, with special reference to British genera and species. Tr. Roy. Entomol. Soc. London 83: $143-176$.

ROBERTS, R. B.

1978. The nesting biology, behavior and immature stages of Lithurge chrysurus, an adventitious wood-boring bee in New Jersey (Hymenoptera: Megachilidae). J. Kans. Entomol. Soc. 51: 735-745.

Robertson, C.

1929. Flowers and Insects. Science Press, Lancaster, PA, 221 p.

SCHMIEDEKNECHT, O.

1930. Die Hymenopteren Nord- und Mitteleuropas. ed. 2. Gustav Fischer, Jena, 1062 p.

StOeCKHeRT, F. K.

1933. Die Bienen Frankens (Hym. Apid.). Deut. Entomol. Z. 1932, Beiheft, 294 p.

1954. Fauna Apoideorum Germaniae. Abhandl. Bayer. Akad. Wissenschaft. n.f. 65 : $1-87$.

TKALCO, B.

1967. Bemerkungen zur Taxonomie einiger paläarktischer Arten der Familie Megachilidae (Hymenoptera, Apoidea). Acta Entomol. Bohemoslov. 64: 91-104. 

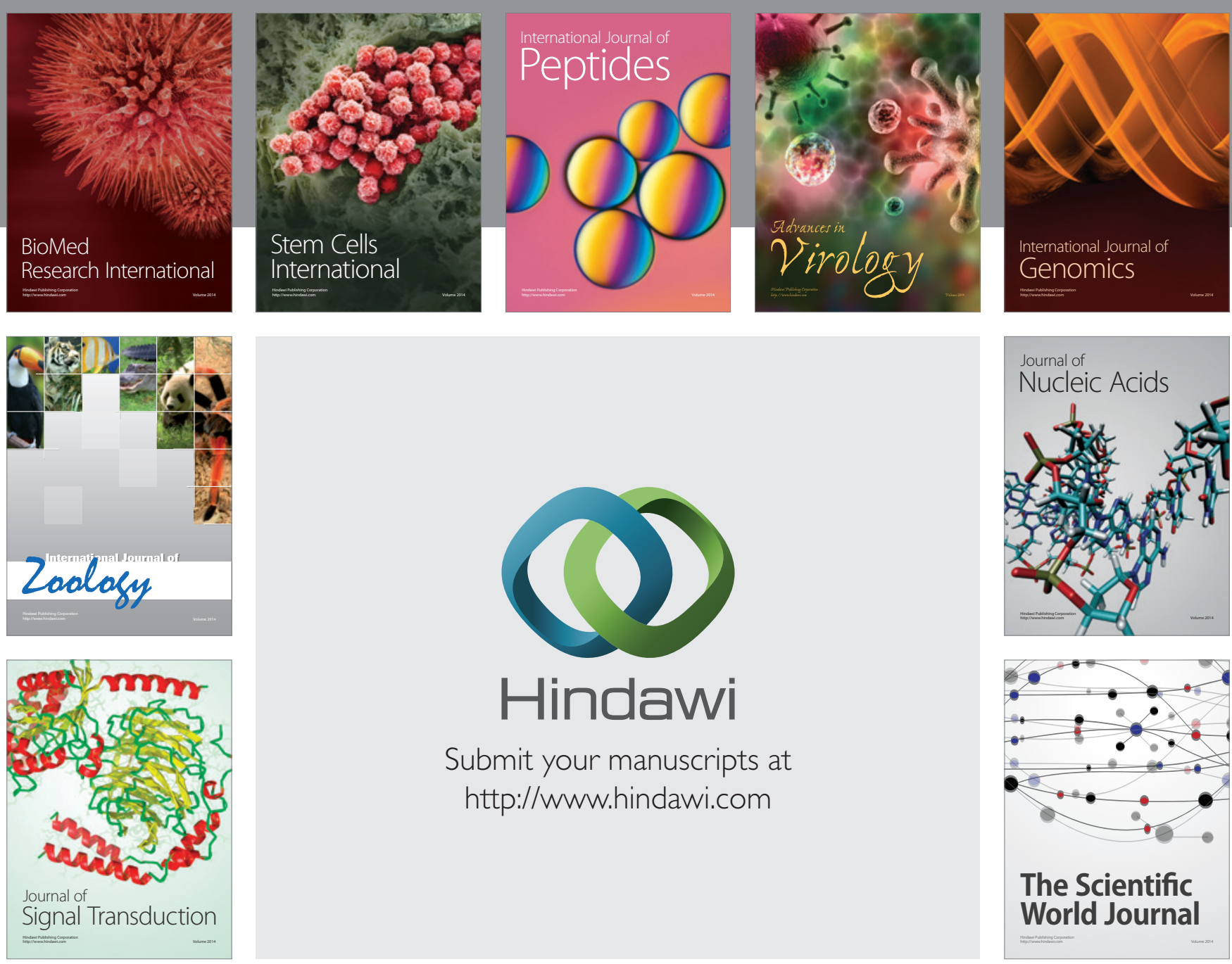

Submit your manuscripts at

http://www.hindawi.com
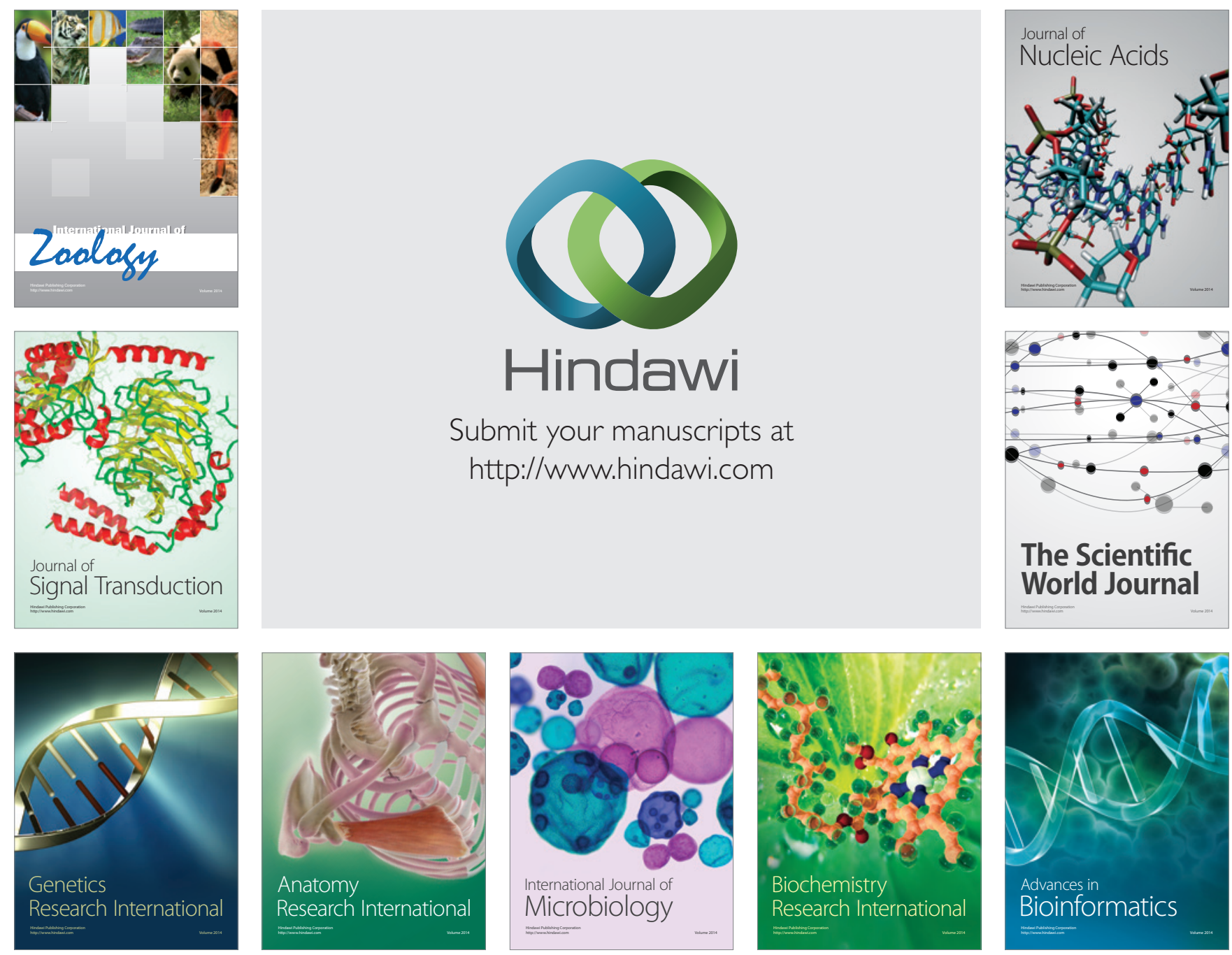

The Scientific World Journal
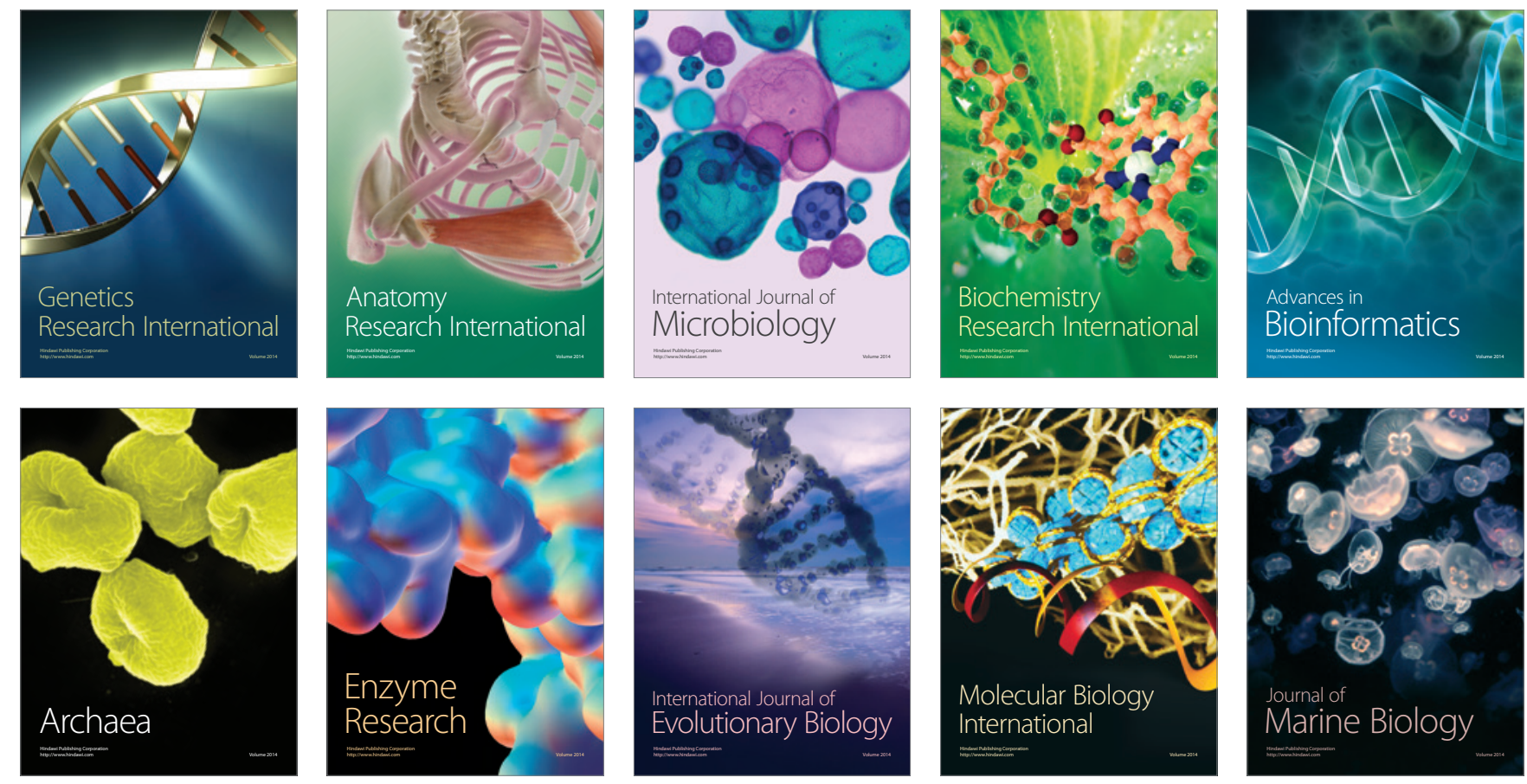